\title{
Effectiveness of Guided Inquiry Model Student Worksheet to Improve Critical thinking Skill on Heat Material
}

\author{
Heri Nurdin ${ }^{1}$, Tri Jalmo ${ }^{2}$,Chandra Ertikanto ${ }^{2}$ \\ ${ }^{1}$ Master Degree Program Student of Physics Education \\ ${ }^{2}$ Master Degree Program Lecturer of Physics Education, Faculty of Teacher Training and Education, University of Lampung \\ herigisting@yahoo.co.id
}

\begin{abstract}
This research aims to describe the effectiveness of guided inquiry model student worksheet to improve critical thinking skill on heat material in terms of learning outcomes. The research used Control Group PretestPosttest Quasi-Experimental Design. The subjects of this research were VII grade of U1 and U2 students of Junior High School 1 with a total of 60 students. The research subjects were determined by using purposive sampling technique. Data collection was conducted by performing test. The results of data analysis with Independent Samples $t$-Test showed sig. value of 0,022. Because sig. value $\leq$ $0,05, H_{0}$ was rejected or $H_{1}$ was accepted. Product effectiveness level based on the mean of normalized gain from pretest and posttest value of experimental and control groups demonstrated that $N$-gain of experimental group was 0,48 and $N$-gain of control group was 0,38 . Therefore, it can be stated that the improvement of students' critical thinking skill of experimental group or group which used development product student worksheet was higher than the improvement of students' critical thinking skill of control group which used conventional student worksheet. It can be concluded that the learning which uses guided inquiry model student worksheet is more effective in improving critical thinking skill than the learning which uses conventional student work sheet.
\end{abstract}

Keywords - student worksheet, guided inquiry, critical thinking skill.

\section{INTRODUCTION}

The quality of education in Indonesia, especially Natural Science (science), is still low. Based on PISA data, Indonesia, in terms of science literacy, always scores far below the international average score. Indonesia can only occupy the top 10 lowest rank of the participating countries (PISA, 2012). The low quality of science education in Indonesia is a manifestation of the application of teaching patterns which are less suited to the demands and the needs of students. The partially applied learning process still uses lecture method that causes students to play a passive role and tend to be the only recipients of science products. The learning process needs to be changed, which is initially teacher-centered,to learning which involves students and challenges them using scientific methods in problem-solving so that it can increase the participation and generate curiosity in learning, improve understanding and mindset as well as help students to develop critical thinking skill. According to Wardani, et al. (2013), students do not only listen to lectures from teachers about a material, but students can also experience the process to get the concept, so that students' understanding of a concept or principle will be greater.

The efforts of government to improve the quality of education are conducted by improving the curriculum, from the Education Unit Level Curriculum (KTSP) 2006 to the 2013 Curriculum. The 2013 curriculum obliges to provide the essence of the scientific approach in learning of science. The scientific approach is an approach that will shapeindividuals to have critical and characterizedattitudes. In order to build the critical and characterized attitudes in students, an appropriate learning model such as scientific discovery learning model, problem-based learning model, and other learning model that build critical and characterized attitudes of the students are needed (Rizqi, et al., 2013; Afidah, et al. 2013).

This scientific approach can be integrated in one of the learning tool components in the form of Student Worksheet (LKS). Student Worksheet, according to Wijayanti, et al. (2015), is a printed material in the form of sheets of paper containing materials, summaries, and instructions on the learning taskimplementation that must be done by the students, which refers to the basic competencies that must be achieved.

One of the purposes of the use of Student Worksheet in science learning is to provide opportunity for students to actively involve themselves in finding a concept through observation and experimental activities, so that the 
learning becomes more meaningful. In developing the teaching materials (Student Worksheet) a proper model is also needed. Learning model which is considered quite effective in science learning is inquiry model (BSNP, 2006).

Inquiryis derived from the word "inquire" which means "seeking" or "questioning". Learning by using inquiry approach, according to Wenning (2011): When taught using the levels of inquiry approach, students have the opportunity to make observation, formulate prediction, collect and analyze, develop scientific principle, synthesize laws, and make and test hypotheses to generate explanation. Guided inquiry learning is more constructive, it gives students the opportunity to ask questions and share learning experiences, as well as to improve students' knowledge and develop critical thinking skill. Guided inquiry learning can make students to think critically. The ability to think critically can tackle the cognitive, affective and psychomotor aspects. It is in accordance with Azwar's research (2015), that students' critical thinking can influence learning outcomes. Critical thinking stimulates each student's cognitive structure to capture ideas, concepts and to organize the knowledge they owned to improve the development of students' proficiency and readiness.

Inquiry is applied in order to make students participate more actively in learning and to find knowledge in their own way. Knowledge that is found by constructing the knowledge itself through real experience will be more meaningful than the knowledge which is remembered or memorized (Sanjaya, 2012). Learning by using inquiry model that is suitably applied to junior high school students is guided inquiry model. The use of guided inquiry is chosen because students have not been accustomed to learn to use inquiry model beforehand.

According to Sagala(2013), thinking is the process of describing the characteristics of an object, placing two relationships between two verbally formulated definitions, and drawing conclusion as the work of reason in the form of a new opinion based on the existing opinion. The ability to think is the basic in a learning process (Heong, et al., 2011). In addition, according to Rustaman (2005), thinking habituation needs to be instilled at the early age through science learning. Critical thinking skill is needed in the current science and technology (IPTEK)development era because the result of Science and Technology(IPTEK)development not only can be enjoyed, but also can generate some impacts that create problems for human life and the environment. The problem is complex enough that it needs high-level thinking skill to solve the problem.
Critical thinking is thinking based on reasons and thinking reflectively by emphasizing decision-making on what should believe or do, Ennis (in Costa ed., 1985). The ability of critical thinking has an important role because it is a provision of life success that prepares students to be clever to explain the reasons, able to make good information assessment and able to solve problems that have not been known (Cheong and Cheung, 2008). Critical thinking skill is included in one of the 21st-century learning and innovation skills that enable students to effectively address social, scientific and practical issues in the future (Snyder and Snyder, 2008).

Students who are accustomed to conduct critical thinking training know more about how to think in a purposeful, planned and logical way according to the facts that have been known so that it can result in the acquisition of more optimal learning outcomes (Haseli \& Rezaii, 2013). Indicators of critical thinking skill are divided into 5 groups (Ennis in Costa ed., 1985) namely: 1) Providing a simple explanation (elementary clarification), 2) Building basic skills(basic support), 3) Making inferences (inferring), 4) Generating further explanation(Advanced clarification), and 5) Setting strategies and tactics (strategy and tactics).

This research aims to describe the effectiveness of guided inquiry model student worksheet to improve critical thinking skill on heat material in terms of learning outcomes.

\section{RESEARCH METHOD}

This research wasquasi-experimental research. The design used in this research was Pretest-Posttest Control Group Design. The subjects of the study were VII grade of U1 and U2 students of SMPN 1 Gisting with a total of 60 students. Research subject was determined by using purposive sampling technique. Research data were collected through critical thinking skill tests. The data analysis of test result was used to measure the effectiveness level of the usage trial (Pretest-posttest Control Group Design) with Independent Sample t-Test. Prior to data analysis, normality test were performed using Kolmogorov-smirnovand homogeneity test with Levene's test.

\section{RESULTS AND DISCUSSION}

\section{The Results of the Research}

The implementation of guided inquiry model student worksheet to improve critical thinking skill was performedduring three meetings for the subject of heat, two meetings for the learning and one meeting for the test. There were five stages of learning approach with inquiry model as stated by Wena (2009), namely: (1) problem 
presentation; (2) Collection of verification data; (3) Collection of experiment data; (4) organization of data and formulation of conclusions; and (5) analysis of inquiry processes.

The level of the concept mastery of students was measured by using the concept mastery instrument in the form of essay test as many as 10 items concerning on heat material. The test instruments used to measure the critical thinking skill were based on indicators of critical thinking skill and, according to Ennis (in Costa ed., 1985), they were outlined from the four dimensions of critical thinking skill namelyproviding simple explanation(elementary clarification), building basic skills (basic support), inferring (inference), and generating further explanation(advanced clarification).

The result of descriptive statistics test of posttest value data in experimentaland control groups can be seen in Table 1.

Table.1: Descriptive Statistics of PosttestResult Value

\begin{tabular}{|c|c|c|c|}
\hline \multicolumn{4}{|c|}{ Data } \\
\hline & & Posttest & Posttest \\
\hline & & Experimental & Control \\
\hline & & Group & Group \\
\hline & Valid & 30 & 30 \\
\hline$N$ & Mising & 0 & 0 \\
\hline Mean & & 70,83 & 67,18 \\
\hline Std. & & 6,86 & 5,01 \\
\hline \multicolumn{4}{|l|}{ Deviation } \\
\hline Minimum & & 58 & 55 \\
\hline Maximum & & 90 & 75 \\
\hline
\end{tabular}

Table1demonstrates that the posttest mean value ofexperimental group is 70,83 andthe posttest mean value ofcontrol group is67,18. This results shows that theposttestmean value of experimental group is higher than theposttestmean value of control group.

The result ofposttestdata normality and homogeneity tests of experimentaland control groupsare presented in Table 2 and Table 3.

Table.2: The Result of Posttest Data Normality Test

\begin{tabular}{ccc}
\hline Group & $\begin{array}{c}\text { Sig. }(2- \\
\text { tailed })\end{array}$ & Conclusion \\
\hline Experimental & 0,200 & Sig. $\geq 0,05=$ Normal
\end{tabular}

\begin{tabular}{lll} 
Control & 0,200 & Sig. $\geq 0,05=$ Normal \\
\hline
\end{tabular}

Table 2 depicts thatthe significance value of experimental group and control group is the same, which is 0,200. It means that sig. (significance) value or probability value of both groups $\geq 0,05$, so that $\mathrm{H}_{0}$ is accepted, which means that the research data are derived from normally distributed data.

Table.3: The Result of Posttest Data Homogeneity Test

\begin{tabular}{cccc}
\hline Levene & $\mathrm{df1}$ & $\mathrm{df} 2$ & Sig \\
\hline 1,826 & 1 & 58 &, 182 \\
\hline
\end{tabular}

Table 3 demonstrates that the significance value of posttest data homogeneity test of experimental and control groups is 0,182 . Because sig. (significance) value or probability value $\geq 0,05, \mathrm{soH}_{0}$ is accepted, which means that both groups have the same or homogeneous variance.

The qualification result of students' critical thinking skillof experimental and control groups based on the mean score of posttestvalue can be seen in the Table 4 .

Table.4: The Qualification of Critical Thinking Skill

\begin{tabular}{ccc}
\hline Group & Mean Score & Category \\
\hline Experimental & 65,5 & Critical \\
Control & 60,68 & Less Critical \\
\hline
\end{tabular}

Source: Dwijananti (2000)

Table 4demonstrates that after conducting a learning using guided inquiry model student worksheet, the result of experimental group development obtains a mean score of 65,5 with 'critical' category, while in the control group, after conducting a learning using conventional student worksheet, a mean score of 60,68 withcritical thinking skill category of 'less critical' is obtained.

The result of difference test of two means between experimental group and control group using t-test (Independent Samples t-Test) can be seen in Table 5. 
Table.5: The Difference of PosttestData Mean

\begin{tabular}{|c|c|c|c|c|c|c|c|c|c|}
\hline \multicolumn{10}{|c|}{ Paired Differences } \\
\hline & & \multirow[t]{4}{*}{ Mean } & \multirow{4}{*}{$\begin{array}{c}\text { Std. } \\
\text { Deviation }\end{array}$} & \multirow{4}{*}{$\begin{array}{l}\text { Std. } \\
\text { Error } \\
\text { Mean }\end{array}$} & \multirow{3}{*}{\multicolumn{2}{|c|}{$\begin{array}{c}\text { 95\% Confidence } \\
\text { Interval of the } \\
\text { Difference }\end{array}$}} & \multirow{4}{*}{$T$} & \multirow{4}{*}{$d f$} & \multirow{4}{*}{$\begin{array}{l}\text { Sig. (2- } \\
\text { tailed) }\end{array}$} \\
\hline & & & & & & & & & \\
\hline & & & & & & & & & \\
\hline & & & & & Lower & Upper & & & \\
\hline \multicolumn{10}{|c|}{ Pair } \\
\hline \multirow[t]{4}{*}{1} & Experimental & 70,83 & 6,865 & 1,253 & & & & & \\
\hline & Group & & & & 0,545 & 6,755 & 2,4 & 58 & 0,022 \\
\hline & Control & 67,18 & 5,008 & 0,914 & & & & & \\
\hline & Group & & & & & & & & \\
\hline
\end{tabular}

Table 5 shows that the sig value. (2-tailed) $<0,05$, so that it rejects $\mathrm{H}_{0}$ and accepts $\mathrm{H}_{1}$. This result indicates that there is a significant difference between the mean value of critical thinking skill of experimental group students and the mean value of critical thinking skillof the control group students. The level of product effectiveness based on the mean of normalized gain of the pretest and posttest values of the experimental and control group is obtained as it is in Table 6.

\begin{tabular}{llll}
\multicolumn{4}{c}{ Table.6: $N$-gainValue of Experimental Group } \\
\hline Group & $\langle g\rangle$ & Classificat & Effectivenes \\
& $(N-$ & ion & s Level \\
& gain $)$ & & \\
\hline Experimental & 0,48 & Moderate & Quite Effective \\
Control & 0,38 & Moderate & $\begin{array}{l}\text { Quite } \\
\text { Effective }\end{array}$ \\
& & & .
\end{tabular}

\section{Source: Hake (2000)}

Table 6 shows that the $N$-gainvalue of experimental group is 0,48 and the $N$-gainvalue of control groupis 0,38 . $\mathrm{N}$-gainvalue of experimental group is higher than the $N$ gainvalue of control group.

The increase of $N$-gain in each dimension of critical thinking skill for each student group is presented in Figure 1.

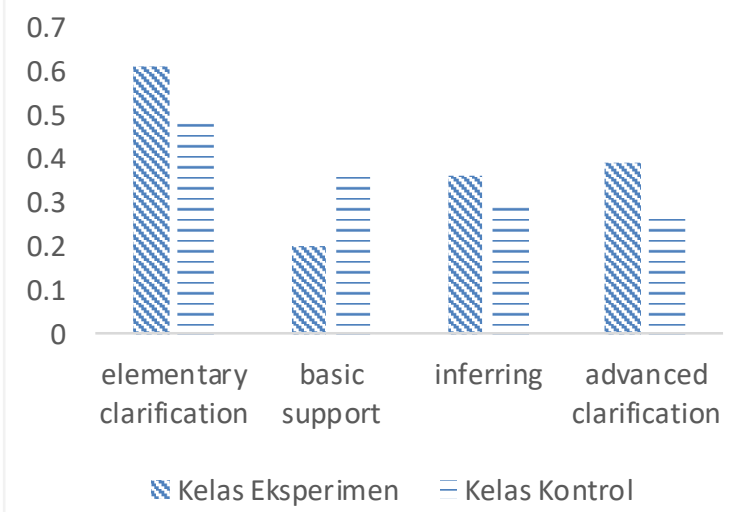

Fig.1: The Increase of N-gain in Each Dimension of Students' Critical Thinking Skill
Figure 1 above indicates that the highest $N$-gain value of critical thinking skill is in the dimension ofelementary clarification (providing simple explanation) either inexperimental group or in control group. While, the lowest $N$-gain of experimental groupis in the dimension ofbasic support (building basic skills).

\section{DISCUSSION}

Hypothesis testing in this research was conducted by using SPSS 21 program.

The results of descriptive statistical test of pretest-posttest value data in the experimental and control groups were obtained that; the mean pretest value of experimental groupwas 33,17 and the mean of pretest value of control group was 35,07 while the mean of value of experimental group was 70,83 and the mean of posttest value of control group was 67,18 . These results indicated that the mean value ofexperimental groupposttest has increased. The mean value of the experimental group posttest wasbigger than the mean value of the control group posttest.

The implementation of guided inquiry model student worksheet resulted in the improvementof student learning outcomes. The student learning outcomes of experimentalgroupwhich usedguided inquiry model student worksheet was greater than the student learning outcomes of control group which used conventional student worksheet. This result also means that students' critical thinking skill in the experimental group were better than the students' critical thinking skill in the control group. The implementation of guided inquiry model student worksheet in the experimental group could improve students' critical thinking ability. This was in accordance with the research conducted by Sochibin's (2009) that the guided inquiry model can improve students'understanding of concepts and develop students' critical thinking skill. The research of Tindangen (2007); Azizmalayeri (2012); Fuad, et al. (2017) proved that 
inquiry learning contributes in improving critical thinking skill.

The student learning outcomes in the experimental groupwere improved due to the learning which usedguided inquiry model student worksheet which allows students to be actively involved both physically and mentally in the learning process. Students gained the experience directly, students were more interested in learning, and student learning motivation increased. These things were supported by previous research conducted by Winarni (2009) who stated,"Through inquiry, teachers invite students to be more active both physically and mentally in the learning process". Rachman et al (2012) stated, "The application of guided inquiry model can improve student learning activities". Laubach et al (2010) said, "With inquiry learning, students can be more interested in the learning that is taught because students get the experience directly". Patrick et al. (2009) said that guided inquiry can improve students' motivation in the learning of science.

The results of Posttest data normality and homogeneity test of experimental and control group in Table 2 and Table 3 showed that posttest data of both groupswere derived from the same or homogeneous and normally distributed variance. Based on this reason, t-test (Independent Samples t-Test) was conducted. Prior to analysis of product effectiveness level using t-test (Independent Sample t-Test), pretest and posttest result data on critical thinking skill assessment were analyzed. The analysis was performed to find out the value of students' critical thinking ability. Having obtained the value of critical thinking skill, the category of critical thinking skill of each student was determined. Categorygiving aimed to know the qualification of critical thinking ability. The result of the students' critical thinking skill qualification in Table 4 showedthat experimental group which used guided inquiry model student worksheet obtained the mean score of the posttestvalue of 65.5 with 'critical' category, while the control group which used the conventional student worksheet obtained the mean score of the posttestvalue of 60,68 with 'less critical'critical thinking skill category.

The result of t-test (Independent Sample t-Test) in Table 5 showed that the sig. value obtained was 0.022 . Because the sig. value $\leq 0.05$ then $\mathrm{H}_{\mathrm{o}}$ was rejected or $\mathrm{H}_{1}$ was accepted, so it could be stated that the learning using guided inquiry model student worksheet improved critical thinking skill more effectively than the learning using conventional student worksheet. Guided inquiry model student worksheet packaged in the student worksheetimproved critical thinking skill more effectively. This was in accordance with the research conducted by Damayanti, et al. (2012) and Sudarmini, et al. (2015).
The product effectiveness level based on the mean of the normalized $N$-gainfrompretest and posttest value of the experimental group and control group obtained the result of the experimental group $N$-gain value of 0.48 with classification of 'moderate' and effectiveness level of'quite effective', while the control group $N$-gainvalue was 0.38 with classification of 'moderate' and effectiveness level of 'quite effective'. Based on the calculation of $N$-gain value, it was known that the $N$ gainvalue of experimental group wasbigger than the $N$ gain value of the control group. Therefore, it can be stated that the improvement of students' critical thinking skill of experimental group or group which used guided inquiry model student worksheet was higher than the improvement of students' critical thinking skills of the control group.

Based on the comparis on of $N$-gain increase in each critical thinking skill dimension for each group of students, the development result of elementary clarification critical thinking skill of experimental group which usedguided inquiry model student worksheet was higher than the development result of control group which used conventional student worksheet. The mean of posttest value from pretest value of experimental group on the critical thinking skill dimension of elementary clarificationincreasedbecause the learning which used guided inquiry model student worksheetallowed students to understand and observe problems from various aspects, to train students to learn in finding problems then make problem formulation based on the facts found. The critical thinking ability of the students was trained and developed by always asking and questioning the various phenomena being studied. It can be attributed to Gengarelly's (2009) research which stated that inquiry could teach students how to ask questions in the classroom and to get their own answers. Inquiry could encourage students' scientific thinking habits and students were more open to new ideas in groups or classes, with the hope that students think about the process, not just the final result. An example of problem formulation by student is shown in Figure 2.

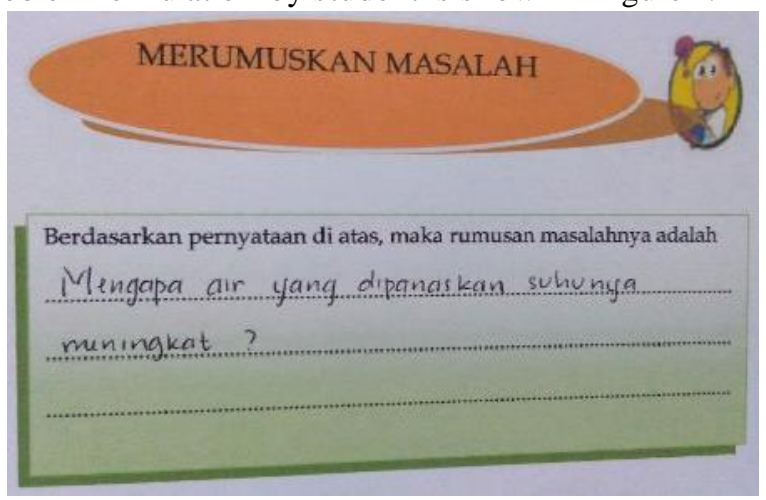

Fig.2: An Example of Problem Formulation 
The problem formulation written by the student is correct. The formula is in accordance with the purpose of the experiment, namely the influence of heat towards the rise in temperature. The orientation stage (guiding the students) of learning steps in using guided inquiry model student worksheet model inquiry has trained students to think critically.

The learning by using guided inquiry model student worksheet also allowedthe students to use the knowledge they have in the form oftemporary answers or hypotheses before conducting experiments. Students' critical thinking skill could be trained and developed through the stage of formulating the problem. This was in accordance with Bilgin's (2009) research that guided inquiry learning model could train students to build answers and think smartly in finding alternative solutions to problems given by teachers, develop understanding skills, and train the delivery process of the conceptsfound. An example of a temporary answer by a student is shown in Figure 3 .

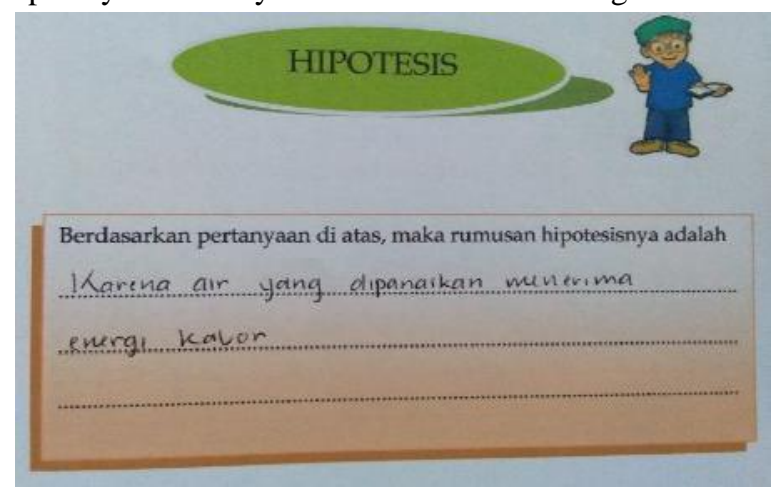

Fig.3: An Example of Hypothesis Formulation

The temporary answer towards the hypothesis formulation put forward by the student is also appropriate. The temperature of an object when heated increased due to the receiving / absorbing energy of heat. Formulating problem stage of learning step in using guided inquiry model student worksheet has trained the students to think critically in using the knowledge they have in the form of temporary answer or hypothesis.

Based on the comparison in $\mathrm{N}$-gainincrease in each dimension of critical thinking skill for each group of students, the critical thinking skill dimension of basic supportof experimental groupwas still lower than control group has (Figure 2), this was possible because students were less accustomed to being trained to think critically in solving problem. Snyder \& Snyder (2008) revealed that like any other skills, critical thinking requires training, practice and patience.

The low result of basic support dimension strengthens that, in the learning which uses guided inquiry model, the teacher does not just let go of the activities undertaken by the students. Teachers still provide guidance and direction in the learning activities so that students who think slowly still able to follow the activities that are being held and the students who have the ability to think fast do not monopolize the activities.

The next step of learning is the collection of verification data. In this step, the students collect the data or information through literature review. An example of collection of verification data by a student is shown in Figure 4.

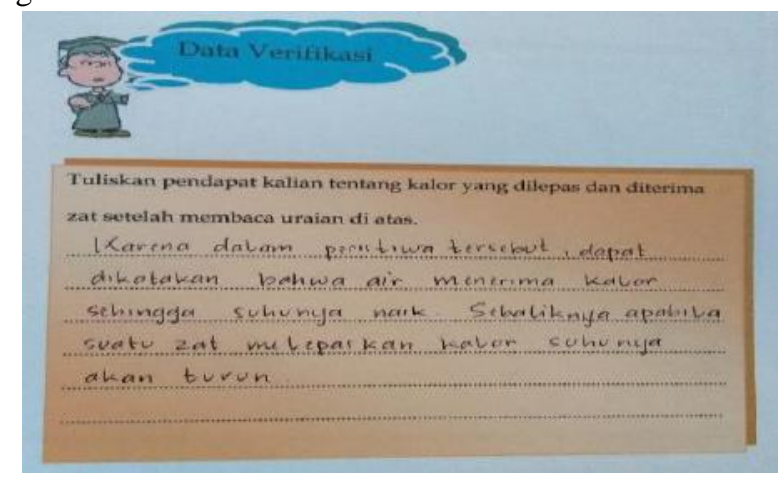

Fig.4: An Example of Verification

\section{Data Collection}

Verification data which have been collected by the student is exactly in accordance with the concept, the water receives / absorbs the heat so that the temperature rises. The verification data trains students to think critically and to sort and choose the correct concept according to the objectives which will be achieved through experiment.

The next step is experimental data collection. Students perform experiments in accordance with the existing procedures, followed by recording the data of experimental results. Experimental activities can help students to understand the material more easily and to gain real experience by taking an active role in learning activities and it can train them to practice investigative skills. This is in accordance with Hackling's (2005) statement that the practice of observation or conducting experiment gives students the opportunity to practice and develop investigative skills as well as to gain real-life experience about natural phenomena as the basis of conceptual learning. Experimental activities can also help students to solve problems and to find their own knowledge. This is in line with Ketpichainarong, Panijpan \& Ruenwongsa (2010) research that students collect data through experimental activities to solve problems so that students are able to build and discover their own concepts of knowledge. An example of data collection by a student is shown in Figure 5. 


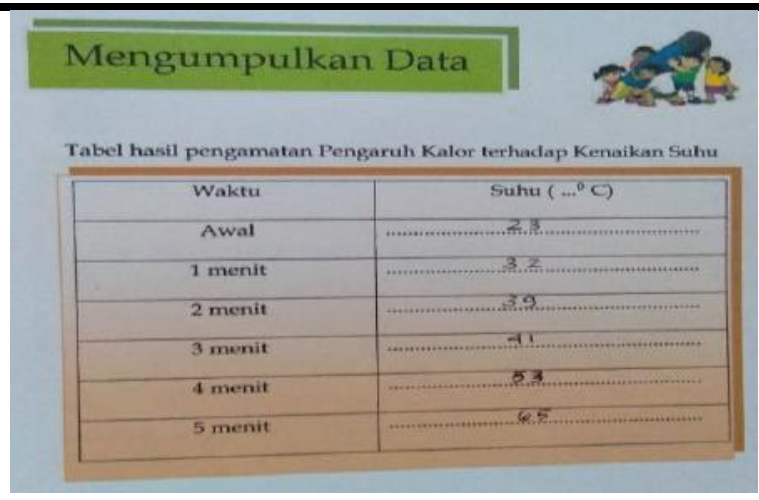

Fig.5: An Example of Experimental

\section{Data Collection}

The resulting data of the experiment collected by the student is correct. The longer the heating time, the higher the temperature rise of the object. The high temperature of the object indicates that the amount of heat received by the object increases.

Based on the experimental data, the students performed data analysis. There is a possibility that the resulting data of experiment and the theory is different, so students need to analyze it. Data analysis begins by examining data and ideas, as well as identifying opinions and supporting reasons. Data analysis activity can be performed by building and using ideas that students owned. This is in accordance with the statement of Callahan, et. Al. (1992: 293-294) that data analysis activity can be done by building and using ideas owned by students. An example of data analysis by a student is shown in figure 6 .

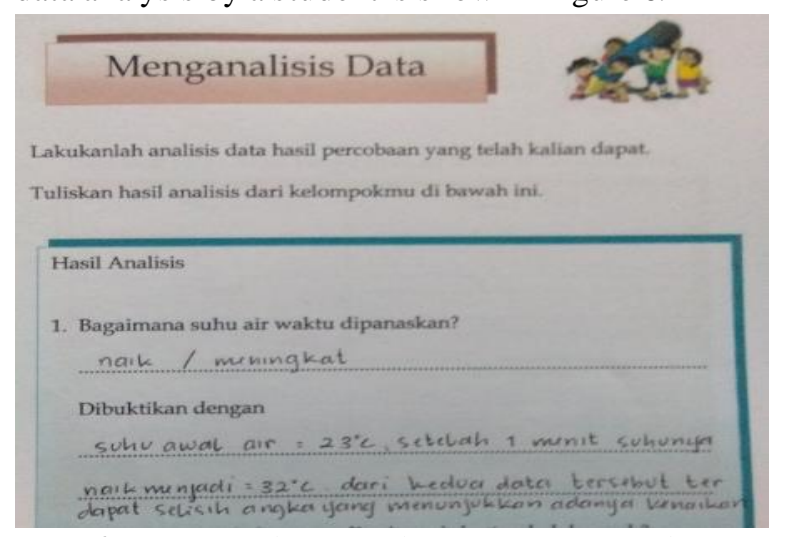

Fig.6: An Example of Analyzing Experimental Data

The analysis of experimental data conducted by the student is correct, water temperature rises when heated, the amount of heat received by the object increases. Data collection and analysis stage of the learning step in using guided inquiry model student worksheet has trained the students to think critically and to summarize a number of raw data into information that can be interpreted.

The next learning step is data organization and conclusion formulation. In this step, the teacher guides students to arrange or interpretthe experimental results.
Teachers also guide students to make a conclusion. An example of conclusions drawn by a student is shown in Figure 7.

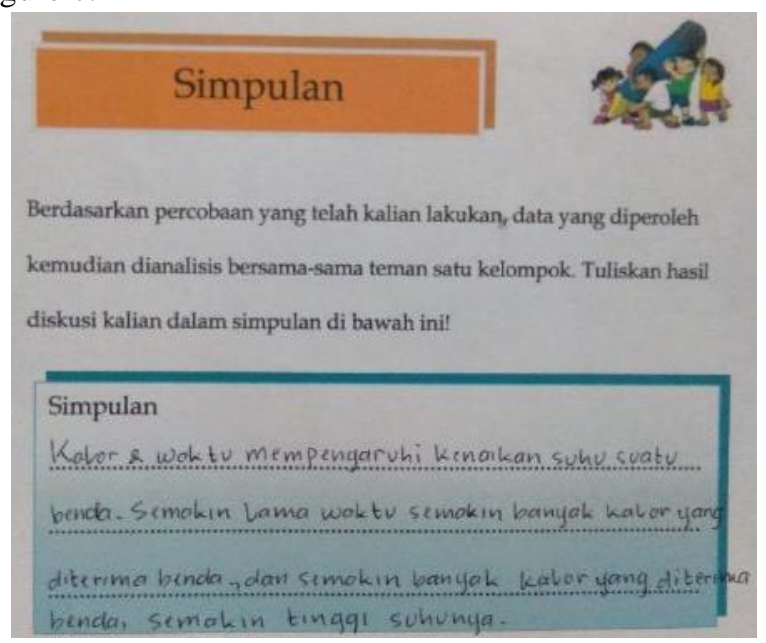

Fig.7: An Example of Conclusion

The conclusion written by the student based on interpretation towards the results of the research is correct. Heat affects the rise in the temperature of the object, the more heat it receives, the higher the temperature of the object. The implementation of guided inquiry model student worksheet in the experimental class can increase the critical thinking skill dimension of inference.

Based on the comparison in $N$-gainincrease for each group of students, the development result of average increase in inference critical thinking skill of experimental group which usesguided inquiry modelis higher than the development result of control group which uses conventional student worksheet. The mean of posttest value from pretest value of experimental group on the critical thinking skill dimension of inferenceincreases because the learning which uses guided inquiry model student worksheetallows students to describe the findings obtained based on hypothesis testing. To reach an accurate conclusion, students should be able to demonstrate relevant data.

Based on the comparison of the increase of $N$-gain in each critical thinking skill dimension for each group of students, the comparis on of pretest and posttest results of critical thinking skills of the experimental and control groups in the advanced clarification critical thinking skill dimension (generating further explanation) and the critical thinking sub defined the terms, considered the definition ofclassification and range. There was an increase in the mean of posttest value frompretest value in advanced clarificationcritical thinking skill dimension of 2.85 in experimental group and of 1.95 in control group. The development result of the increase in mean value of advanced clarificationcritical thinking skill of experimental class which used guided inquiry model 
student worksheet was higher than the development result of the control group which used conventional student worksheet. The mean of posttest value from pretestvalue of experimental group on advanced clarification critical thinking skill dimension increasedbecause the learning which used guided inquiry model student worksheetallowed the students to be actively involved in finding their own concept through observation or experiment so that learning activities became more meaningful.

The average increase ofposttest value frompretest value in all dimensions of critical thinking skill in the experimental group showed that the learning using guided inquiry model can improve students' academic proficiency. This is supported by the research conducted by Sari \& Sutiadi (2008) that the observed academic abilities were improved after applying guided inquiry learning model. Jannah et al (2012) stated that the implementation of guided inquiry could improve the quality of students' conceptual understanding and was able to embed the characters in the students. Wirtha (2008); Suma (2010); Handhika (2010) said that guided inquiry learning could develop the mastery of physics concept.

The average increase of posttest value frompretest value in all dimensions of critical thinking skill in the experimental group also showed that the learning using guided inquiry model student worksheet improved students' critical thinking skill. This was supported by Hasruddin' (2009) research which stated that the application of inquiry learning can empower students' thinking skill so that it couldmaximize the critical thinking skill. Prabowo et al (2015) stated that the critical thinking skill of students who were taught with inquiry learning model has increased.

\section{CONCLUSION AND SUGGESTION}

\section{Conclusion}

Based on the results of research and discussion, it can be concluded that learning by using guided inquiry model student worksheet packaged in student worksheet is quite effective toimprove critical thinking skill. The results of $N$ gain calculation showed that the $N$-gainvalue of group which used development product student worksheet was higher than the value of the group which used conventional student worksheet. $N$-gainvalue of experimental group was 0.48 and $N$-gainvalue of control group was 0.38. The implementation of guided inquiry model student worksheet in the experimental group can improve students' critical thinking skill.

\section{Suggestion}

Suggestions from this development research are: (1). Teachers and studentsshould be able to use guided inquiry model student worksheet as a means to improve critical thinking skill. (2). This new development research is conducted on a small scale, hence, further research on large-scale groups should be carried out to determine the feasibility of this product to be applied to large-scale groups.

\section{REFERENCES}

[1] Afidah, A.R.R., Erman, B., \& Budiyanto, M. 2013. Penerapan Model Pembelajaran Berdasarkan Masalah pada Pembelajaran IPA Terpadu Tema Korosi Besi untuk Siswa Kelas VII SMP Negeri 1 Bungah Gresik. Jurnal Pendidikan Sains, 1 (1): 66-70.

[2] Amilasari, A. \& Sutiadi, A. 2008. Peningkatan Kecakapan Akademik Siswa SMA Dalam Pembelajaran Fisika Melalui Penerapan Model Pembelajaran Inkuiri Terbimbing. Jurnal Pengajaran MIPA, FPMIPA UPI, 12 (2): 1-8.

[3] Azizmalayeri, K., MirshahJafari, E., Sharif, M., Asgari, M., \& Omidi, M. (2012). The Impact of Guided Inquiry Methods of Teaching on The Critical Thinking of High School Student. Journal of Education and Practice,3 (10): 1-7.

[4] Azwar, M. 2015. Pengaruh Pembelajaran Inkuiri Terbimbing dan Inkuiri Bebas Termodifikasi Terhadap Prestasi Belajar Ditinjau dari Berpikir Kritis dan Kedisiplinan Belajar Siswa Kelas X MIA SMA Negeri 8 Surakarta Tahun Pelajaran 2014/2015. Jurnal Inkuiri, 4 (3): 127-135.

[5] Badan Standar Nasional Pendidikan. 2006. Panduan Penyusunan Kurikulum Tingkat Satuan Pendidikan Jenjang Pendidikan Dasar dan Menengah.Jakarta: Depdiknas.

[6] Bilgin, I. 2009. The Effect of Guided Inquiry Instruction Incorporation a Cooperative Learning Approach an University Student, Achievement Acid and Based Concepts and Attitude Toward Guided Inquiry Instruction. Academics Journal Scientific Research and Essay, 4 (10): 1038-1046.

[7] Callahan, J.F., Clark, L.H., \& Kellough, R.D. (2002). Teaching in The Middle And Secondary Schools. New York: Macmillan Publishing Company.

[8] Cheong, C.M., \& Cheung, W.S. 2008. Online Discussion and Critical Thinking Skill: A Casestudy in a Singapore Secondary School. Australasian Journal of EducationalTechnology, 24 (5):556-573.

[9] Costa,A.L.1985.The Prinscipal's Rolein Enhancing Thinking Skill. Dalam Costa A.L. (ed). Developing 
Mind: A Resource Book for Teaching thinking. Alexandria: ASCD.

[10] Damayanti, D.S., Ngzizah, N. \& K.E., Setyadi. 2012. Pengembangan Lembar Kerja Siswa (LKS) dengan Pendekatan Inkuiri Terbimbing untuk Mengoptimalkan Kemampuan Berpikir Kritis Peserta Didik pada Materi istrik Dinamis SMA Negeri 3 Purworejo Kelas $\mathrm{X}$ ahun Pelajaran 2012/2013.Jurnal Radiasi, 3. (1): 58-62.

[11] Dwijananti, P., \& Yulianti, D. 2010. Pengembangan kemampuan berpikir Kritismahasiswa melalui pembelajaran problem based instruction pada mata kuliah fisika lingkungan. Jurnal Pendidikan Fisika Indonesia (Indonesian Journal of Physics Education), 6 (2): 108-114.

[12] Fuad, N.M., Zubaidah, S., Mahanal, S., \& Suarsini, E. (2017). Improving Junior High Schools Critical Thinking Skills Based on Test Three Different Models of Learning. International Journal of Instruction, 10 (1): 101-116.

[13] Gengarelly, L.M. \& Abrams, E.D. (2009). Closing the Gap: Inquiry in Research and the Secondary Science Classroom. Journal of Science Education and Technology. 18 (1): 74-84.

[14] Hackling, M.W. (2005). Working Scientifically: Implementing and Assessing Open Investigation Work in Science. Western Australia: Departement of Education and Training.

[15] Hake, R.R. 2000. Interactive-engagement vs traditional methods: A six thousand student survey of mechanics test data for introductory physics courses. American Journal of Physics, 66, p. 64-74.

[16] Handhika, J. 2010. Pembelajaran FisikaMelalui Inkuiri Terbimbing dengan Metode Eksperimen dan Demonstrasi ditinjau dari Aktivitas dan Perhatian Mahasiswa, $J P 2 F, 1$ (1): 9-23.

[17] Haseli, Z., \& Rezaii, F. 2013. The Effect of Teaching Critical Thinking on Educational Achievement and Test Anxiety among Junior High School Student in Saveh. European Online Journal of Natural and Social Sciences, 2(2): 168-175.

[18] Hasruddin. 2009. Memaksimalkan Kemampuan Berpikir Kritis Melalui Pendekatan Kontskstual. Jurnal Tabularasa PPS UNIMED. 6(1): 4860.Diperoleh 12 April 2018, dari: http//digilib.unimed.ac.id/public/UNIMED-Article24572-Hasruddin.pdf.

[19] Heong, Y.M., Yunos, J.M., Hassan, R.B., Othman, W.B., Kiong, T.T. 2011. The Perception of The Level Of Higher Order Thinking Skills among Technical Education Student. International Conference on Social Science and Humanity
Journal. Faculty of Technical Education, Universiti Tun Hussein Onn Malaysia, 5 (2): 281-285.

[20] Jannah, M., Sugianto \& Sarwi. 2012. Pengembangan Perangkat Pembelajaran Berorientasi Nilai Karakter Melalui Inkuiri Terbimbing Materi Cahaya Pada Siswa Kelas VIII Sekolah Menengah Pertama. Journal of Innovative Science Education, 1 (1): 5460.

[21] Ketpichainarong, W., Panijpan, B., \& Ruenwongsa, P. 2010. Enhanced Learning of Biotechnology Student by An Inquiry-based Cellulase Laboratory. International Journal of Environmental\& Science Education, 5(2): 169-187.

[22] Laubach, T.A., Elizondo, L.A., McCann, P.J., \& Gilani, S. 2010. Quantum Dotting the "i” of Inquiry: A Guided Inquiry Approach to Teaching Nanotechnology. The Physics Teacher Journal. University of Oklahoma, Norman, OK, 48: 186-188.

[23] Patrick, H., Mantzicopoulos, P. \& Samarapungavan, A. 2009. Motivation for Learning Science in Kindergarten: Is There a Gender Gap and Does Integrated Inquiry and Literacy Instruction Make a Difference. Journal of Research In Science Teaching, 46 (2): 166-191.

[24] PISA, 2012. Organisation for Economic Cooperation and Development (OECD). [Online]. Tersedia: oecd.Org/statistic/statlink. [12 Desember 2014].

[25] Prabowo, L.S.B. \& Sunarti, T. 2015. Penerapan Model Pembelajaran Inkuiri pada Materi Alat Optik untuk Meningkatkan Keterampilan Berpikir Kritis Siswa Kelas VIII SMP Cendekia Sidoarjo. Jurnal Inovasi Pendidikan Fisika, 4 (1): 6-11.

[26] Rachman, N.D., Sudarti, \& Supriadi, B. 2012. Penerapan Model Inkuiri Terbimbing(Guided Inquiry Aproach) Pada Pembelajaran Fisika Siswa Kelas VII-B SMP Negeri 3 Rogojampi Tahun Ajaran 2012/2013. Jurnal Pembelajaran Fisika, 1(3): 143-151

[27] Rizqi, A., Parmin, P., \& Nurhayati, S. 2013. Pengembangan Modul Ipa Terpadu Berkarakter Tema Pemanasan Global untuk Siswa SMP/MTs. Unnes Science Education Journal, 2 (1): 203-208.

[28] Rustaman, N.Y. 2005. Perkembangan Penelitian Berbasis Inkuiri Dalam Pendidikan Sains. Makalah disampaikan dalam seminar Nasional II Himpunan Ikatan Pascasarjana dan Pemerhati Pendidikan IPA. FP MIPA UPI. Bandung 22-23 Juli 2005.

[29] Sagala, S. 2013. Konsep dan Makna Pembelajaran. Bandung: Alfabeta.

[30] Sanjaya, I.P.H. 2012. Pengaruh Model Pembelajaran Inkuiri Laboratorium terhadap Keterampilan Berpikir 
Kreatif dan Keterampilan Proses Sains Siswa Ditinjau dari Kemandirian Belajar Siswa. Jurnal Penelitian Pascasarjana Undiksha, 2(2): 1-15.

[31] Sudarmini, Y., Kosim \& Hadiwijaya, A.S. 2015. Pembelajaran Fisika Berbasis Inkuiri Terbimbing dengan Menggunakan LKS untuk Meningkatkan Keterampilan Berpikir Kritis Ditinjau dari Sikap Ilmiah Siswa Madrasah Aliyah Qamarul Huda Bagu Lombok Tengah. Jurnal Penelitian Pendidikan IPA, 1. (1): 35-48.

[32] Snyder, L.G., \& Snyder, M.J. 2008. Teaching Critical Thinking and Problem Solving Skills. The Delta Pi Epsilon Journal,L(2): 90-99.

[33] Sochibin, A,. Dwijananti, P., \& Marwoto, P. 2009. Penenrapan Model Pembelajaran Inkuiri Terpimpin untuk Peningkatan Pemahaman dan Keterampilan Berpikir Kritis Siswa SD. Universitas Negeri Semarang (Unnes), Semarang, Indonesia. Jurnal Pendidikan Indonesia, 5: 96-100.

[34] Suma, K. 2010. Efektivitas Pembelajaran Berbasis Inkuiri dalam Peningkatan Penguasaan Konten dan Penalaran Ilmiah Calon Guru Fisika. Fakultas MIPA, Universitas Pendidikan Ganesha, Jurnal Pendidikan dan Pengajaran, 43 (6): 47-55.

[35] Tindangen, M. (2007). Implementasi Strategi Inkuiri Biologi SMP serta Pengaruhnya terhadap Kemampuan Berpikir Tingkat Tinggi. Jurnal Pendidikan, 8 (2): 1-9.

[36] Wardani, S., Anna, P., Asep, K., \& Buchari. 2013. Kecerdasan Logical Mathematics Berbasis Aktivitas Inkuiri Laboratorium. Jurnal Inovasi Pendidikan Kimia, 7(3): 1129-1137.

[37] Wena, Made. 2009. Strategi Pembelajaran Inovatif Kontemporer. Jakarta: Bumi Aksara.

[38] Wenning Carl, J. 2011. Level of Inquiry Model of Science Teaching: Learning Sequences to Lesson Plant. Department of Physics. Illinois University, Normal, IL, USA. Journal Physics Teacher Education online, 6(2), 17-20.

[39] Wijayanti, P.I., \& Hindarto, N. 2010. Eksplorasi Kesulitan Belajar Suswa pada Pokok Bahasan Cahaya dan Upaya Peningkatan Hasil Belajar Melalui Pembelajaran Inkuiri Terbimbing. Jurnal Pendidikan Fisika Indonesia, 6: 1-5.

[40] Winarni, E. 2009. Pengembangan Model Pembelajaran Inkuiri Terbimbing dan Masyarakat Belajar untuk Meningkatkan Pemahaman Konsep dan Life Skill Siswa Sekolah Dasar. Jurnal Pendidikan Dasar, 10 (1): 1-7.

[41] Wirtha, N.K. 2008. Pengaruh Model Pembelajaran dan Penalaran Formal terhadap Penguasaan Konsep Fisika dan Sikap Ilmiah Siswa SMA Negeri 4
Singaraja. JPPP, Lembaga Penelitian Undiksha, Jurnal Penelitian dan Pengembangan Pendidikan, 1 (2): $15-29$. 